Meta

Journal des traducteurs

Translators' Journal

\title{
Lolita's Love Affair with the English Language: Heterolingualism and Voice in Translation
}

\section{Margarida Vale de Gato}

Volume 63, numéro 2, août 2018

URI : https://id.erudit.org/iderudit/1055142ar

DOI : https://doi.org/10.7202/1055142ar

Aller au sommaire du numéro

Éditeur(s)

Les Presses de l’Université de Montréal

ISSN

0026-0452 (imprimé)

1492-1421 (numérique)

Découvrir la revue

Citer cet article

Vale de Gato, M. (2018). Lolita's Love Affair with the English Language: Heterolingualism and Voice in Translation. Meta, 63(2), 322-341. https://doi.org/10.7202/1055142ar
Résumé de l'article

Cet article est un compte rendu à la première personne de la traduction de Lolita en portugais. Il s'attache surtout à savoir comment ne pas considérer l'anglais seulement comme une langue source qui devrait être remplacée par la langue de traduction. Le roman souligne la stridence du narrateur comme signe d'un « illusionniste non indigène " (Nabokov 1955/1991 : 317), ce qui accentue l'hétérolinguisme et présente des défis de traduction remarquables : comment représenter la géopolitique de l'hybridité linguistique dans le texte cible ; comment maintenir l'ambiguïté des rapprochements entre lecteur(s), auteur(s), et d'autres instances d'autorité diégétique, y compris le « traducteur fictif» (Klinger $2015: 16)$ ?

La non-traduction sélective est proposée comme un choix pour faire face à l'hybridité linguistique, à travers laquelle, dans ce contexte, les « voix différentielles » (Hermans 2007 ; Suchet 2013) peuvent affirmer les différences et les déviations linguistiques (et donc, culturelles/idéologiques). L'adhésion à une stratégie de " traduction ouverte " (House 2001) ne vise pas à rompre le " pacte du traducteur " (Alvstad 2014) ; pourtant, la convention de transparence est rejetée. Cela permet de contourner l'autorité phonocentrique en faveur d'un palimpseste polyphonique orchestrant une archéologie du langage - pas une étrangéisation à tout prix, mais une disponibilité pour «l'altérité du langage » (Bakhtine 1981).
Ce document est protégé par la loi sur le droit d'auteur. L’utilisation des services d'Érudit (y compris la reproduction) est assujettie à sa politique d'utilisation que vous pouvez consulter en ligne.

https://apropos.erudit.org/fr/usagers/politique-dutilisation/ 


\title{
Lolita's Love Affair with the English Language: Heterolingualism and Voice in Translation
}

\author{
MARGARIDA VALE DE GATO \\ Universidade de Lisboa, Lisbon, Portugal \\ mgato@fl.ul.pt
}

\section{RÉSUMÉ}

Cet article est un compte rendu à la première personne de la traduction de Lolita en portugais. Il s'attache surtout à savoir comment ne pas considérer l'anglais seulement comme une langue source qui devrait être remplacée par la langue de traduction. Le roman souligne la stridence du narrateur comme signe d'un «illusionniste non indigène » (Nabokov 1955/1991: 317), ce qui accentue l'hétérolinguisme et présente des défis de traduction remarquables: comment représenter la géopolitique de l'hybridité linguistique dans le texte cible; comment maintenir l'ambiguïté des rapprochements entre lecteur(s), auteur(s), et d'autres instances d'autorité diégétique, y compris le «traducteur fictif» (Klinger 2015: 16)?

La non-traduction sélective est proposée comme un choix pour faire face à l'hybridité linguistique, à travers laquelle, dans ce contexte, les «voix différentielles» (Hermans 2007; Suchet 2013) peuvent affirmer les différences et les déviations linguistiques (et donc, culturelles/idéologiques). L'adhésion à une stratégie de «traduction ouverte» (House 2001) ne vise pas à rompre le «pacte du traducteur» (Alvstad 2014); pourtant, la convention de transparence est rejetée. Cela permet de contourner l'autorité phonocentrique en faveur d'un palimpseste polyphonique orchestrant une archéologie du langage - pas une étrangéisation à tout prix, mais une disponibilité pour «l'altérité $d u$ langage » (Bakhtine 1981).

\section{ABSTRACT}

This article is a first-person account of the translation of Lolita into Portuguese dealing primarily with the question of how to treat English as a source language that should be replaced by the translating language. The novel foregrounds the narrator's stridency as a non-"native illusionist" (Nabokov 1955/1991: 317), along with a heterolingual bend, presenting remarkable challenges for translation: how to represent the geopolitics of linguistic hybridity in the TT and how to maintain the ambiguity of alignments between (implied) reader(s), author(s) and competing instances of narratorial authority, including the "fictional translator" (Klinger 2015: 16).

Selective non-translation is suggested as an option for addressing linguistic hybridity through which, in this context, the "differential voice(s)" (Hermans 2007; Suchet: 2013) might foreground linguistic (and hence cultural/ideological) difference and deviation. The adherence to a strategy of "overt translation" (House 2001) is not intended to break the "translator's pact" (Alvstad: 2014); it refuses, however, the convention of transparency as one of its tenets. It also shifts the focus from phonocentric authority to a polyphonous palimpsest and an archaeology of language(s) - not an entrenched foreignization, but an availability for "other-languagedness" (Bakhtin: 1981).

\section{RESUMEN}

Este artículo es un testimonio en primera persona de la traducción de Lolita al portugués. Fundamentalmente, se ocupa de la cuestión de cómo utilizar el inglés como un idioma de partida que debe substituirse por el idioma de la traducción. La novela subraya la voz estridente del narrador como la de un "ilusionista no-nativo" (Nabokov 1955/1991: 317). 
Esa voz acentúa el heterolingüismo y vuelve más compleja aún la tarea del traductor. ¿Cómo representar la geopolítica del sincretismo lingüístico en el texto de llegada y cómo preservar las ambigüedades propias de los puntos de contacto entre lector(es) y autor(es) implicados, tal y como de otras instancias de autoridad diegética, incluyendo la del "traductor ficticio" (Klinger 2015: 16)?

La no-traducción selectiva se propone como una forma de enfrentar el sincretismo lingüístico, a través de la cual, en este contexto, "las voces diferenciales" (Hermans 2007; Suchet 2013) contribuirían a acentuar las diferencias y las desviaciones lingüísticas y, también, culturales e ideológicas. La adhesión a un tipo de "traducción abierta" (House 2001), como estrategia, no busca romper con el "pacto del traductor" (Alvstad 2014); por ello, la convención de la transparencia se abandona. Estas decisiones permiten rehuir la autoridad fonocéntrica y favorecer un palimpsesto polifónico y una arqueología del lenguaje. No se trata de una extranjerización forzada, sino de un estado de disponibilidad hacia la "alteridad del lenguaje" (Bakhtine 1981).

\section{MOTS-CLÉS/KEYWORDS/PALABRAS LLAVE}

traduction littéraire, hétérolinguisme, non-traduction sélective, voix en traduction, négotiation entre éditeur et traducteur.

literary translation, heterolingualism, selective non-translation, voices in translation, publisher-translator negotiation.

traducción literaria, heterolingüística, non-traducción selectiva, voces en traducción, negociación entre editor y traductor.

\section{Introduction}

What follows is a reflection on my Portuguese version of Lolita, with a focus on the issue of differential voices and languages. ${ }^{1}$ I write not only from the point of view of the literary translator with a strong investment on discussing the ethics of linguistic hybridity and transference, but also from the perspective of someone experienced in teaching and researching what, to follow George Steiner, I would prefer to call "an exact art," rather than "a science" of translation (1998: 109).

I agree with the scholarly reasoning, famously advocated by Berman (1985/2000) and Venuti $(1995,1995 / 2008)$, that for a translation to be literary it should measure up to the defamiliarization created by literature, by steering away from a smooth read not offered by the source text. I believe literary translation ought to pursue a resistant alienness, striving to match the linguistic audacity with which the source text manipulates its own language - or rather language(s), at least in the case of the novel, which Bakhtin (1981) demonstrated to be composed of diverse idioms. But how should the translator handle a text that addresses through its main narrator, Humbert Humbert (itself a name that can be duplicated in several languages), the circumstance of English not being, as a source material, a native tongue per se?

Metalinguistic commentary throughout the book belies the not-quite homely English used by its narrator, who chooses to define himself as a "brand-new American citizen of obscure European origin” (Nabokov 1955/1991: 105), bemused by “American parlance" (198), particularly so by Lolita's speech: "the reader will notice what pains I took to speak Lo's tongue" (149). In the afterword, the authorial voice ironizes about impersonating Vladimir Nabokov and underscores how his polyglot immigrant condition parallels the narrator's: 
My private tragedy, which cannot, and indeed should not, be anybody's concern, is that I had to abandon my natural idiom, my untrammeled, rich, and infinitely docile Russian tongue for a second-rate brand of English, devoid of any of those apparatuses - the baffling mirror, the black velvet backdrop, the implied associations and traditions

- which the native illusionist, frock-tails flying, can magically use to transcend the heritage in his own way. (Nabokov 1955/1991: 316-317)

This essay concerns the metalinguistic rationale to be considered when approaching the task of translating a novel whose narratorial overlap of language as medium and language as object harbors the reflexivity of (self-)translation (Klinger 2015: 16-18). My preferred method has been to foreground the visibility of translatorial ideation, somehow following to the letter the term coined by Juliane House, overt translation, whereby "the original's frame and discourse world are co-activated, such that members of the target culture may 'eavesdrop', as it were, i.e., be enabled to appreciate the original textual function" (House 2001: 250). "Eavesdropping" is a fitting description of what I meant to achieve through the application of a strategy I call selective non-translation, taking a cue from Meir Sternberg's "selective reproduction," a means of keeping polylingualism in the fictional world through an "intermittent quotation" of the fictive speaker's discourse in a different language (Sternberg 1981: 225). It was my intention to reinstate the primacy of (American) English as reporting language in a hybrid discourse by electing ST passages and retaining their original form. In the end, though, I fell short of a consequent application of this strategy, which would arguably accentuate the heterolingualism of the novel and fulfill the purpose of restoring its balance. My publisher allowed only a few English intromissions (most of them calques already existing in Portuguese), on the basis that the reader need not be distracted by English phrases "artificially" highlighted by my intervention. Because he explicitly objected to my (pre)conception of a theory for the practice of this translation, the quarrel raised doubts and insights that I will share as a contribution to the discussion on how to go about translating linguistic hybridity in fiction, namely when the narrator, often posing as a fictional translator, makes a show of compromising with the rising ascendancy of one brand of English.

\section{Language (h)as character: hybridity and voice(s)}

Nabokov's afterword to Lolita, which since 1956 has been appended to most editions of the novel, foregrounds the role of English in the novel:

[A]n American critic suggested that Lolita was the record of my love affair with the romantic novel. The substitution "English language" for "romantic novel" would make this elegant formula more correct. But here I feel my voice rising to a much too strident pitch. (Nabokov 1955/1991: 314)

Ambiguously duplicating the predicament of his narrator, the author anticipates himself as "implied," and raises, literally, the issue of voice. The "rising to a much too strident pitch" points to the delusion of the dramatized narrator that Nabokov fashioned after Edgar Allan Poe's murderer-cum-narrators. The author of "Annabel Lee," frequently invoked, is a likely model for Humbert Humbert's tone of hysteria, toppled by pedantism. ${ }^{2}$ The narrator's voice in Lolita, however, is much more polyphonous than any of Poe's narrators and uncannily postmodern in its use of self-irony and reflexivity. Its extensive quotationalism - credited citations, clever allusions or 
playful use of idioms, "subvert[ing] history, continuity, and memory" (Capranzano 1995: 138) - increases the stratification of speech types and voices, which Bakhtin famously identified as "heteroglossia" (Bakhtin 1981: 262-263).

Bakhtin's term already comprised a superimposition of languages, but Meir Sternberg, acknowledging how novels were increasingly engaging with multilingual contexts, employed the term "heterolingual" to denote "a foreign language (or dialect) - usually a language other than that of the reporting speech-event" (Sternberg 1981: 222; Grutman 1997; Meylaerts 2006). Its use being fictional, Sternberg stresses the mimetic quality that differentiates heterolingualism from polylingualism in actual interactions, leading to a degree of restraint and framing of foreign utterances. Sometimes there is no attempt to transcribe the foreign idiom, but the reader is informed that the language used at the level of the story-world is different from that of the narration, as in the strategy that Sternberg calls "explicit attribution." This, in which "the text tells that the speech was delivered in another language, even if it doesn't represent it" (Sternberg 1981: 231-232), is sometimes used in Lolita, as in this example:

1) She answered (I translate from her French which was, I imagine, a translation in its turn of some Slavic platitude): 'There is another man in my life."'

(Nabokov 1955/1991: 17, italics mine)

Being more precise, these lines can also illustrate one more of the four devices Sternberg singled out for translational mimesis, "conceptual reflection," which occurs when the speech contains metalinguistic commentary on the different referential framework(s) of languages (Sternberg 1981: 230-3). In the example above, the narrator points to the fact that the speech act of a character does not conform to the language of her thought act, alluding to an intercultural and cross-linguistic struggle that matches his own. But not quite. The notion of thought act is important for the twentieth-century first-person narrator, so often occupied by interior monologue and stream of consciousness. Humbert Humbert's discourse reveals a self-conscious mindset, since it shows awareness that he is not narrating precisely what he thinks, that he is performing thought acts, which therefore are indistinguishable from speech acts, governed by socio-linguistic norms: "if you can still stand my style (I am writing under observation)" (Nabokov 1955/1991: 10). As regards the other two heterolingual devices defined by Sternberg, "verbal transposition" (the main language is interspersed with word-for-word translation, syntactic or pragmatic features of foreign discourse) and "selective reproduction" (representative samples of foreign speech or thought acts), we find they are much more often used to report a fundamentally polyglot mind, the narrator's own (Sternberg 1981).

Although we know that the narrator is trying hard to interiorize a preferred form of speech, "Lo's tongue" (Nabokov 1955/1991: 149), we do not really know, unlike the character who thinks in Slavic but talks in French, which is Humbert Humbert's first language, or whether he has one. We suspect not, precisely because of the numerous instances involving conceptual reflection, verbal transposition, and selective reproduction of more than one different language, not for the sake of realism of dialogue, but for rendering voice(s) that reverberate within the one who speaks. The overlapping voices are appropriate for a self-conscious character who sometimes conveys his "fancies" in the third person, as in the following example: 
2) [T] hat first impression ... carried the clear implication that all widower Humbert had to do, wanted to do, or would do, was to give this wan-looking though suncolored little orphan aux yeux battus (and even those plumbaceous umbrae under her eyes bore freckles) ... nice girl-friends of her age among whom (if the fates deigned to repay me) I might find, perhaps, a petty little Mägdlein for Herr Doktor Humbert alone. But "in a wink," as the Germans say, the angelic line of conduct was erased, and I overtook my prey (time moves ahead of our fancies!)

(Nabokov 1955/1991: 111)

Susanne Klinger's recent book on representing translation in "hybrid-English" literatures, ${ }^{3}$ elaborates on Sternberg's hint at the distinction between, on the one hand, translational mimesis proper (when a different language or variety is symbolized as object in the story world), and, on the other, the representation of translation embedded in the medium of representation, which she associates with represented self-translation (Klinger 2015: 17-20). She goes on to explain the effects of this distinction at the level of narration or character presentation and posits the figure of narrator as "fictional translator," or mediator of the linguistic hybridity that is representative of the story world (Klinger 2015: 16). Depending on whether this representation is carried out through reported and indirect speech or constituent of the diegetic discourse, we have, respectively, symbolic hybridity when the "fictional translator" symbolizes the language of an/other, or iconic hybridity, when (s)he is representing his/her self-translation:

Iconic hybridity, on the other hand, is the product of representing the self-translation performed by a character or an embodied narrator and therefore represents hybridity as object. The representation of this self-translation is immediate, or rather, it purports to be immediate. This verbatim reproduction is of course an illusion, as all speech and thought presentation is mediated by the narrator [...]

Furthermore - and more importantly for the argument I develop here - in the case of this type of hybridity, we, as the readers, are expected to suspend our disbelief and imagine that these are the actual words spoken or thought by the character or the embodied narrator. (Klinger 2015: 20)

Humbert Humbert's readers are led to imagine that his polyglot utterances correspond to the actual words of his thought acts; therefore, I would say that most of the time the linguistic hybridity in Lolita falls into the category of iconic hybridity (except when he is reporting another's utterance as foreign, as in the case of the Slavic lover above, which falls into that of symbolic hybridity). ${ }^{4}$ The term represented selftranslation, however, is elusive on at least two counts: first, "self-translation" itself is probably a misnomer, since what comes across is a distancing strategy, as pointed out by Granqvist's critique of the term in relation to the works of Achebe: "he is doing the opposite of what the term might imply, depersonalizing his self" (Granqvist 2003: 70); second, in many cases, with Nabokov as with many African English writers, you cannot really tell if the narrator is translating from some other, radically different, anterior or more native language. In fact, as Klinger notes further on, hybrid English used as iconic representation does not oppose two different languages, but rather an idea of norm and its departure, the standard and the non-standard. Whereas "symbolic hybridity," representing another language, signifies otherness and different ethnicity, "iconic hybridity," pointing to idiosyncratic variety, "highlights in-betweenness" (Klinger 2015: 137). 


\section{Criteria for selective non-translation}

I have endeavored to represent in my Portuguese translation of Lolita the narrator's commitment to a "second-rate brand of English" (Nabokov 1955/1991: 317) through a procedure I have called selective non-translation. This is a somewhat "passiveaggressive" mode of compensation for literary linguistic hybridity through codeswitching (García Vizcaíno 2008). Since it privileges parts of text that were unmarked in the original, it is a highly interventional strategy. Nonetheless, the rationale for compensation which underlay my option also considered that the translated text, were it to keep the heterolingualism of phrases in French and other languages, as previous translations into Portuguese had done, could be unduly marking foreignisms while erasing the cultural implications of the hybrid English texture. The circumstance that my commission was a retranslation and that it implied a re-examination of the source text ${ }^{5}$ - along with an ideology largely shaped by my academic research on the dislocation of heterolingualism in translation (Vale de Gato 2015) - compelled me to try this experimental strategy, while not precluding hesitations about its effectiveness and implication in terms of language politics.

Foregrounding the English language is, on the one hand, deferential to its cultural prestige (Zauberga 2001: 268), and, on the other, liable to contribute to the minoritarization of other languages, increasingly vulnerable to the hyper-centrality of English. If we take Lolita as a groundbreaking masterpiece of postmodern multilingualism or of diasporic and/or exile literature in the US, the Humbert-Lolita relationship is pertinent to the discussion of which groups are entitled to own English, and of how such control depends on the gap between old and young - morals, education, manners, desires and drives. My drive was to stage English in the translation as it is duplicitously staged throughout the English source text, where it is also forged and literarily reinvigorated by the newcomer's foreignization. I strove to be systematic about it and defined a few criteria for considering non-translation, ranked below by degrees of "loudness," so as to prepare the discussion of the practical objections of my publisher and the more specious misgivings of theory concerning the (ab)use of a translator's voice. I shall present them with examples from my intended translation, the published version, and, whenever relevant, from previous translations into Portuguese, accompanied by back translations.

\subsection{Specialized-Knowledge Terms}

This includes terms pertaining to specific activities or jurisdiction with no equivalent in the target language, like the legal phrases girl-child and wayward child, or names of tennis moves, like back-hand or half-volley, some of them already established as foreignisms in Portuguese. That there is always a fair amount of leeway for foreignisms in these cases is proven by their usage in previous translations as well, even if not always consistently. Regarding volley terms, for instance, the previous translator into European Portuguese opted once for “rebate de revés” (Nabokov 1955/1974: 168, translated by Pinto Rodrigues) as a paraphrase for "backhand stance" (1994: 162), but used a loanword for the same term on another occasion: "escolher entre o seu forehand e o seu backhand" (Nabokov 1955/1974: 241, translated by Pinto Rodrigues) In what concerns legal terms, it is worth noticing that the literal strategy of loanwords 
was adopted only by Brenno Silveira in the first Portuguese translation (1959) - in keeping with his tendency for lexical foreignization that will be discussed below.

\subsection{Culturemes}

According to Nord (1997: 34), these are culture-specific references with no evident equivalent in the target language. I decided not to translate lexical markers denoting the late-40s suburban American culture satirized in the novel, even if most of these instances were later questioned by the publisher and do not appear in the published version.

3) She was Lola in slacks.

(Nabokov 1955/1991: 9)

a) Era Lola de slacks.

b) Era Lola em seus slacks.

(Author's unpublished translation)

(Nabokov 1955/1968: 13, translated by Silveira)

c) De calças práticas, era Lola.

[In casual pants, she was Lola.]

(Nabokov 1955/1974: 9, translated by Pinto Rodrigues)

d) Era Lola ao vestir os jeans desbotados.

[She was Lola in bleached jeans.]

(Nabokov 1955/1994: 11, translated by Dauster)

e) Era Lola de calças compridas.

[She was Lola in long pants.]

(Nabokov 1955/2011: 9, translated by Siqueira and Flaksman)

4) [. . . the lovely, inane, lost look that Lo had when gloating over a new kind of concoction at the soda fountain.

(Nabokov 1955/1991: 76)

a) [... ] o encantador e inane olhar perdido de Lolita, quando se babava diante de uma nova mistela na soda fountain.

(Author's unpublished translation)

b) [... ] o olhar perdido, adoravelmente fútil, com que Lô agraciava um novo tipo de sundae

(Nabokov 1955/1994: 84, translated by Dauster)

In Example 3, it is interesting to note that my proposed translation was not original, as it had been used by Brenno Silveira. Remarkably, his seminal translation seems to have followed a coherent strategy of not translating technical or cultural lexical terms, and we find throughout the text such italicized choices as breakfast, partner, starlet, canyon, and also - curiously enough, as it might point towards an exoticization of Humbert Humbert's love preferences - nymphet and any word of the same lexical family (e.g. nimpholepts). My publisher, however, held fast to the belief that any cultural designation can withstand a paraphrase, and also feared that many terms would be opaque for today's readership. The proof that slacks is a cultureme resides ironically in the fact that none of the other translations seem to agree on what exactly are slacks, which is why in the end I opted for the compromise of a generalization (just calças, meaning pants - 2013: 17) - even if slacks would also have the 
advantage of preserving the original sensual alliteration. In Example 4), the publisher thought that a paraphrase of soda fountain, the Portuguese phrase loja de refrescos ("refreshments' store") would be better, but he allowed for an endnote clarifying the concept in the source culture (Nabokov 2013: 86, 337, translated by Vale de Gato). The paraphrasing strategy had also been used in the previous translation to European Portuguese, but only with loja de sorvetes, or "ice-cream store" (Nabokov 1974: 87, translated by Pinto Rodrigues). I have transcribed the solution adopted in Dauster's translation to Brazilian Portuguese as well, because he discarded the attempt at paraphrase/explanation found in the other translators. Instead, he effected an interesting hyponymy, opting for a loanword that has been incorporated into Brazilian Portuguese ("sundae").

\subsection{Allusions to English and US literature}

I opted not to translate the citations from English-language literature, since the narrator's style is affected by his idea of literary English, at least as much as by literature quoted in other languages. It is worth noting that in the following example, the final Portuguese translation retained the English of Edgar Allan Poe's poem Annabel Lee (1849/1969), but a paraphrase in Portuguese (quando éramos os dois crianças) was added to comply with the publisher's request.

5) When I was a child and she was a child, my little Annabel was no nymphet to me; [...]

(Nabokov 1955/1991: 17)

a) When I was a child and she was a child, quando éramos os dois crianças, não me ocorreria que a minha pequena Annabel fosse uma ninfeta; [...]

(Nabokov 1955/2013: 26, translated by Vale de Gato)

b) Quando eu era criança e ela também, minha pequena Annabel não era para mim uma nymphet.

(Nabokov 1955/1968: 24, translated by Silveira)

c) Quando eu era criança e ela era criança, a minha Anabela não era uma ninfita para mim.

(Nabokov 1955/1974: 18, translated by Pinto Rodrigues)

In the previous Portuguese translations, the allusion to Poe's Annabel Lee ${ }^{6}$ is at best opaque; in the 1974 version, since the girl's name is naturalized to Anabela, it is totally lost. The translation by Brenno Silveira opts for an awkward code-switching with the word nymphet, but it does not, at this time or previously (in the opening paragraphs that gloss the royal location by the sea and the envious seraphs of Poe's ballad), allude to the American poet's literary influence. In my version, this time in agreement with the publisher, endnotes were added to reference the identified literary sources (whether from English-speaking or other literatures), following The Annotated Lolita (1955/1991). The previous translators or editors did not deem this necessary, with the sole exception of a footnote in Pinto Rodrigues's Lolita, referencing the character Miranda in Shakespeare's Tempest (1974: 151). 


\subsection{Conceptual reflection about the uttered language}

I chose not to translate metalinguistic expressions on the part of the narrator involving language as medium, especially those deemed ancillary to the narrative progress. One example is the occurrence of the word Waterproof, which creates an associative link between two different episodes in the text, one in which the narrator fails in his attempt to drown Lolita's mother, and the other when he is about to know who replaced him in Lolita's affections. In the architecture of the novel, this seems to have been a phrase crucial enough for Nabokov to recall it in his afterword (Nabokov 1955/1991: 316), and, furthermore, to have opted for a curious phonological transcription of the English word in his own Russian translation of Lolita, which he undertook in 1963-65.

Another example concerns the phrase "One last word" in the following passage, whereby we are made aware that narrative pathos is often indissociable from a shift between reported thought in a foreign language (mostly French) and direct speech in English. Furthermore, in an aside to his elocution, the narrator admits those might not have been the exact words spoken, disclosing the credibility gap between translational mimesis and represented self-translation.

6) Carmencita, lui demandais-je...

"One last word," I said in my horrible careful English, "are you quite, quite sure that - well, not tomorrow, of course, and not after tomorrow, but - well - some day, any day, you will not come to live with me? I will create a brand new God and thank him with piercing cries, if you give me that microscopic hope" (to that effect).

(Nabokov 1955/1991: 280)

Carmencita, lui demandais-je... Só mais uma palavra [One last word] - disse eu no meu terrível e precavido inglês - tens mesmo a certeza, toda a certeza que... bem, é possível que não seja amanhã, claro, nem depois de amanhã, mas... bem... um dia, qualquer dia, não podes vir viver comigo? Sou capaz de criar um deus novinho em folha e agradecer-lhe com gritos lancinantes, se me deres nem que seja uma esperança microscópica - (ou coisa que o valha).

(Nabokov 1955/2013, translated by Vale de Gato: 296)

Although in the translated instance I would have been happier if One last word came with no square brackets and without the paraphrase, the fact is I settled for what the publisher would allow, retaining at least the SL reminder of the cruciality of metalanguage in this passage. It is worth noting that most previous translations had opted for direct speech in Portuguese but maintained the allusion to the "horrible careful English" (horrível e meticuloso inglês in Nabokov 1974: 319, translated by Pinto Rodrigues; or cuidadoso e horrível inglês in Nabokov 1968: 357, translated by Silveira), which also puts into question the fiction of translation while incongruously disturbing the verisimilitude of speech. The most reader-friendly option in what regards the delusion of facing the work itself is perhaps the shift of emphasis in Dauster's Brazilian Portuguese, where the explicit attribution of language is omitted in favor of register and tone: disse eu com meu estilo horrivelmente empolado ("I said in my terribly pompous style") (Nabokov 1994: 316).

\subsection{Expressions perceived as American English idioms or turns of phrase}

This is admittedly a subjective category, since it is not always obvious when a particular construction is a "repertoreme" (Toury 1991: 186) of some cultural community. 
I reasoned, however, that there were some vernacular expressions of American English, which, if left untranslated and interspersed with the Portuguese text would create an illusion of polyglotism that matched the effects of the French idioms already scattered in the ST. Thus, in example (6) quoted above, starting precisely with French and an intertextual reference to Mérimée, I would like to have left untranslated not only "One last word," but also "brand new God":

(7) Carmencita, lui demandais-je...

- One last word

- disse eu no meu terrível e precavido inglês - tens mesmo a certeza, toda a certeza que... bem, é possível que não seja amanhã, claro, nem depois de amanhã, mas... bem... um dia, qualquer dia, não podes vir viver comigo? Sou capaz de criar um brand new God e agradecer-lhe com gritos lancinantes, se me deres nem que seja uma esperança microscópica - (ou palavras que o valham).

(Author's unpublished translation)

\section{Publisher's resistance}

As hinted at above, after intense discussions, I barely got away with "One last word," and definitely not with "brand new God." The most immediate consequence of my strategy of selective non-translation was the resistance from the director of the publishing house, compelling me to retract the disclosure of the source language in many instances. Figure 1 shows a list of the non-translation instances intended for the first forty translated pages, of which the final book retained only those that are not crossed out.

FIGURE 1

Overruled selections of non-translations for Lolita in Portuguese

p. 4 (and always) - slacks

p. 4 - prott

p. 5 - pout you lowe thus

p. 6 - frock

p. 8 - When I was a child and she was a child (with paraphrase in Portuguese)

p. 9 - girl-child, young person and wayward child

p. 17 - grts

p.19 - whom I'd coach in French

p. 2 - funnies

p. 21 - praias technicolor

p. 25 (and always) - futes

p. 27 - rodopiar bastonetes de cheerleader

p. 27 (and always) - Midwest

p. 28 by the side of my darling - my darling - my life and my bride (with translation in an endnote)

p. 29 -

p. 30 - band-aid

p. 31 - hot fudge

p. 32 -

p. 35 - p.

p. 38 - Iadore her so horribly

p. 39 - sugarless breakfast

p. 40 - p. 40 -

p. 40 - Offer

p. 42 - "muito British"

p. 43 - To hold thee lightly in a summer breeze

p. 45 (and always) -

p. 45 (and always) -

p. 45 - Great Little Town 
The most censored situations were those involving culturemes and my own rationale for "American English turns of phrase." Looking back at the instances in fig. 1, now, I am unsure as to the complications entailed by some of my choices - for example, maintaining in English the phrase "Whom I'd coach in French," which might further hinder comprehension for non-proficient English readers (even if I am still particularly sensitive to the nuance of "coach" by a narrator whose tutoring ideal involved the blending of intense physical and mental exercise). For what it is worth, the source-text's French passages were not a very easy read for an American English audience either. When I pointed this out to the publisher, he had a moment of hesitation that captured what I perceived as a conservative and somewhat patronizing stance towards literary translation. He questioned whether the very Gallicisms and other foreignisms should be kept, insisting, moreover, on the need for the mediating role of endnotes. I realized then that my publisher was no advocate for the free play of voices within translated novels, which back in 1994 Rachel May had affirmed to be the imprint of "translations that owe a conceptual debt to Bakhtin and narratology” (May 1994: 5). ${ }^{8}$ I argued that even if Portuguese readers' knowledge of French had decreased since Pinto Rodrigues, in her first translation of the novel in 1974, the text still held approximately the same degree of translatability as that between English and French at the time of Nabokov's writing. And certainly, Nabokov had not taken any pains to assuage the reader's understanding. Incidentally, the decline of French as a second language in Portugal is a result of its replacement by English, which accounts for a generation gap in foreign-language competence. The publisher and I had different pre-conceptions regarding the English proficiency of current Portuguese readers of literature. Confronted with my views, his retort was to the effect that perhaps I should not have constructed a theory about my translation task.

I believe, as much as Venuti $(1995,1995 / 2008)$ and Steiner (1975/1998) in their somewhat different hermeneutic vein, that a great deal of ethical responsibility comes with the power of shaping a readership granted by translation. I think, furthermore, that in the case of literature this responsibility has to be complemented by a measure of boldness in gauging the aesthetics of the present place vis-à-vis the horizon of the source text. The latter, as argued by João Barrento, is still "the only and the most stable possible reference, within the boundaries of meaning and interpretation" (Barrento 2002: 38; my translation), but it is up to the translator to evaluate the distance and difference of boundaries of the ethical-aesthetic compound. Considering aesthetic effect in Lolita, I would say that what Martin Amis dubbed "special intonations [of cruelty]" (Amis 1992: 111) still reverberate in our 'end-of-Alice era, ${ }^{9}$ but their translation impact will suffer if those intonations are not linguistically foregrounded by the aesthetic friction of heterolingualism in the novel.

Certainly, the discernment and consequent action upon what in a text is geopolitical, or interculturally ideological, implies a degree of interpretation on the part of the translator that some readers might find intrusive, if not misguided. Another passage that was discarded by the publisher in my first version was the exaggeration of heterolingual effect in a misogynistic sexual innuendo in direct speech (to Lolita) by Humbert Humbert: 
(8) [... ] I deplore the Mann Act as lending itself to a dreadful pun, the revenge that the Gods of Semantics take against tight-zippered Philistines. I am your father, and I am speaking English, and I love you.

(Nabokov 1955/1991: 150)

[. . .] desprezo essa lei, a que também chamam Mann e é um trocadilho pavoroso em inglês, uma vingança dos deuses da semântica contra os filisteus e as suas braguilhas estreitas. Eu sou o teu pai, I am speaking English and I love you.

(Author's unpublished translation)

As I had already added that "Mann" was a pun in English ("trocadilho pavoroso em inglês"), the publisher thought it unnecessary to further convoke the English language. To be sure, I was giving emphasis to the utterance of love in different languages - which was perhaps undue, but justifiable, as I love you lacks the solemnity of Amo-te in Portuguese, as well as the exquisiteness of aimer, in French, later underlined by Lolita's narrator: "turpid, and everything, mais je t'aimais, je t'aimais!" (Nabokov 1955/1991: 284). ${ }^{10}$

Nevertheless, it remains true that in the case of other foreignisms present in Lolita, it was ultimately the author who decided to plant them; in the case of Anglicisms, they could only be placed in the translated text through my active selection of otherwise unmarked parts of discourse. This issue raises interesting theoretical implications regarding my non-translation strategy: the interference of the translator with the narrator's voice, or the creation of a "translator's narrator" (Schiavi 1996: 8-9; Suchet 2013: 5-6). In the last section of this article, I will touch upon the dispute whether it is desirable or even possible for the reader to overhear a "translator's voice" that is distinct from the (implied) author's. In the next section, I will address how, in any case, translation, especially when dealing with highly heterolingual texts, affects the focalization by the narrator on characters, and consequently the degree of "allegiance" the reader establishes with these diegetic instances (Smith 1995: 83).

\section{The translator's narrator of the narrator-cum-translator}

The option of marking through non-translation passages that constitute the discourse of a homodiegetic narrator risks an imbalance of "deictic priming" (Klinger 2015: 128) by privileging not only the referential world of the narrator, but also his language of reference in relation to other languages. In other words, if Humbert Humbert is a "translator narrator" of sorts, I might, by exercising my "translator's narrator" prerogative in such a way as to explicitly conflate his ideational and linguistic point of view, coax the reader into a stronger allegiance with how Humbert Humbert sees cultural context that harbors American English. It is possible, therefore, that my translational ethos meddles with the already shifty notion of whether the implied author wants the reader to (dis)approve of Humbert Humbert's worldview.

The hesitation to sympathize with the narrator is perhaps the most remarkable accomplishment of Lolita. The diverse responses within the cline of discordance to complicity with Lolita's unreliable principal narrator and the lingering doubt about the textual author's moral inclination were issues that greatly upset the ethical standards of Wayne Booth in his The Rhetoric of Fiction (Booth 1961), ${ }^{11}$ The rhetorical strategies underlying the construction of Humbert Humbert's voice(s), to which 
heterolingualism and strenuous convolutions of English are integral, have elicited heated debates among narratologists ever since (Phelan 2007). The pulverization of authority in Lolita's narration is compounded by the craft of embedded narrative, with the dramatization of editorial intervention ("John Ray, Jr., PhD.," signing the preface) and by the "impersonation of Vladimir Nabokov" (Nabokov 1955/1991: 311) in its afterword of 1956. The translator's narrator is one more entity dividing what Murray Smith, in his description of the "structure of sympathy" of cinematic narration, defined as "alignment," roughly the same as focalization: "the process by which spectators are placed in relation to characters in terms of access to their actions and to what they know and feel" (Smith 1995: 83). In my proposed translation of Lolita, the verbatim transcription of parts of speech from the source text would give the reader the illusion of eavesdropping on the shifts in perception created by the alternation of English with other languages. On the other hand, it might shift slightly the level and quality of "allegiance" pertaining to the realm of the audience's ideological and moral evaluation of characters - including the narrator. For instance, in accentuating the contrast between the "Britishness" Charlotte perceives in the narrator and her insistence on choosing French as the language of love, my option for the following translation might lead the reader to sympathize with Humbert Humbert's disdain for the stereotypification of foreign cultures by the American divorcée:

(9) My dearest, mon très, très cher, what a world of love I have built up for you during this miraculous June! I know how reserved you are, how "British."

(Nabokov 1955/1991: 68)

Meu querido, mon très, très cher, oh, o mundo de amor que eu criei para si neste milagroso junho! Sei bem como é reservado... muito «British»!

(Nabokov 2013: 78)

The reader's sense of the translator's interference might influence his understanding of the intentionality of authorship. It happens that the (co-)authorship of translation is a unique phenomenon, making literary translation a unique genre in the sense that the writer starts out as reader of the text s/he writes, and unquestionably a very implied one at that. Thus, as Boase-Beier puts it, "translators have to know what they think the writer meant" (Boase-Beier 2011: 90), and so it really is a challenge for the translator of Nabokov to figure out whether the implied author of Lolita likes his principal narrator or not. To this day, however, I cannot say I have a clear idea about this, considering that my focus on polyglotism might slant the presentation of the hypocritical pedophile's reasoning against convention, even if, on the other hand, it points to a transvaluation of behavioral differences through competing languages, which otherwise would have been lost in translation.

Boyden and Goethals have also explored how the presence of heterolingualism enhances "solidarity effects embedded in the ST onto the relation between the implied author and reader of the TT" (Boyden and Goethals 2011: 20), and how shifts in code-switching through translation can alter the narratee's empathy towards the narrator's cultural in-betweenness. In this line of thinking, I would like to recuperate the notion of a translator's voice interfering with the implied author's. I wonder if, by disclosing the voice of the narrator of the source language in Lolita, I might be scratching the surface of the (over)writing of translation, and if so, whether that impacts the discussion of the voice of the translator. Therefore, I shall discuss the 
narratological import of the subgenre literary translation of fiction, commenting on what the translator's visibility means to me, including what I think might be overlooked by not acknowledging the added value of differential language - and voice(s) - in translation.

\section{Who / What Speaks in Translated Narrative}

In his 1996 article “The Translator's Voice in Translated Narrative," Hermans examines several instances of "disparities within the discourse itself [that] prevent the conventional suspension of disbelief and bring into focus the linguistic as well as pragmatic displacement consequent upon the act of translation" (Hermans 1996: 37). These translator's intromissions - including cases of "self-referentiality involving the medium of communication itself” (Hermans 1996: 28) similar to those found in Lolita - ultimately support "a model of translated narrative which [. . .] needs to incorporate the Translator as constantly co-producing the discourse" (Hermans 1996: 43). In the same issue of Target, Schiavi (1996) designed the first prototype for this model, later clarified by Munday as shown in Figure 2.

\section{FIGURE 2}

Narratological representation of ST and TT (Munday 2008: 12)

ST

author - implied author - narrator - narratee - implied reader - ST reader

TT

ST reader/translator - impled translator - TT narrator - TT narratee - TT implied reader - TT reader

In terms of alignment, the reader's mapping of the narrator onto the author of the TT (the translator) might be infrequent, even if, according to Klinger: "[t]he more accentuated this awareness of reading a TT - that is, a mediated version of the words of the ST author - the more likely it is that the TT reader maps both the ST and the TT author (or characteristics of each one of them) onto the TT narrator" (Klinger 2015: 119). Cautiously, perhaps, Klinger does not phrase the TT author as an "implied translator." Alvstad (2014) has recently contested such a notion as something that severs the translation pact by which the translator faithfully represents the words of the author. Drawing on Chatman's representation of the narrative-communication situation, where the implied author is a conjectural figure with "no direct means of communication" (Chatman 1978: 148), Alvstad ascribes to him - or rather to it - as the structuring principle of the work, "not an entity that can be doubled or replaced" (Alvstad 2014: 275). Therefore, she concludes:

the implied author will be reconstructed by readers in very much the same way regardless of whether they read a translation or a non-translated text, and [...] the discursive presence of the translator in the translated text is just one of many voices (and other indexical signs) out of which the individual reader will reconstruct the implied author. $(\text { Alvstad 2014: 275) })^{12}$

These arguments, nonetheless, can be challenged on several counts:

1. the notion that there can only be one structuring principle of a work. Alvstad corroborates Chatman on this, who argued there is always one implied author, even when 
the real author is diffuse (Chatman 1978, 149). This may be so, but we should not preclude the likely hypothesis of the reader constructing two or more implied authors - or two, maybe more, structuring principles - in cases where the empirical people associated with the authorship stimulate a differential imagination on the part of the reader, for instance, an epistolary novel signed by two great authors, or a narrative translated by an important figure (Baudelaire's Edgar Allan Poe, for example);

2. the notion of translator as just one more voice in the narrative. Since Alvstad admits that " $[\mathrm{w}]$ hen a literary text is translated, the indexical signs that make up the stylistic, ideological and aesthetic properties change, and therefore ... the objective side of the implied author changes" (Alvstad 2014: 275), then the translator is supposedly active in the construction of the structuring principle(s) of the narrative. We could therefore re-evaluate Munday's scheme, possibly erasing the figure of the "implied translator," but representing the co-authorship by the author and one reader (the translator), both influencing the construction of the implied author as a unique feature of the translated literary text - and here, the tentative scheme of the competing authorities that possibly inhabit it:

TT: STAuthor and ST Reader/Translator - implied author(s) - TT narrator(s) [+ character's voice(s), indexical signs]

If we admit the translator has a voice, then it would necessarily follow that the author also has one. Contemporary narratology has been so keen to distance narrative from empirical people that this idea might be stunning. Nonetheless, it is a hypothesis I think Bakhtin wished us to consider in his analysis of the functions of free indirect speech in the novel: "such a form permits another's inner speech to merge, in an organic and structured way, with a context belonging to the author" (Bakhtin 1981: 310). Once we are willing to give voice to the author, imaginary or not, in the novel, a third tenet of Alvstad's argument might be challenged;

3. the notion of a voiceless implied author. It is here pertinent to follow Suchet's questioning of the voicelessness of any text, arising precisely from her analysis of the translator as a "spokesperson." Defying what she calls the "phonocentric illusion" that demands the correspondence of one voice to one presence, Suchet argues for the replacement of the term voice with that of ethos, a "differential" category implying, in translated narrative, negotiations between the discursive figures of reader, translator and author (Suchet 2013: 171). This seems a clever realization, even if it risks obscuring the narratological category of voice, whose descriptive potential relies on the discrimination between instances of narrative control and construction.

For my part, I would like to reclaim "the translator's voice" as a narratological category that makes translation a different genre, and one that can be literary (as fiction can be literary or not). We might call it a "differential voice," as Hermans also did (Hermans 2007: 32), taking his cue from Folkart's discussion of translation as re-enunciation, as well as from her felicitous metaphor of the interference of two waves in a very close frequency:

[...] une somme de différences plus ou moins minuscules, plus ou moins hétéroclites, une série de dissonances intermittentes et fugaces analogues aux interférences acoustiques, battements produits par deux ondes de fréquence rapprochée. (Folkart 1991: 395-396)

The closeness of this frequency is important. The translator's voice, as I have suggested, should not be an alternative or a replacement of the "author's" voice - however 
subjective, implicit or intentional -, but a complementary one which strives to be unisonous with it, even if $s /$ he misses the mark. By reassessing the question of the "translator's voice," I do not mean to defend the visibility of translation at the cost of received interpretation, nor do I mean to contest the translation pact that asserts the translator can be trusted as qualified to render the words of the author as best s/he can. I am only suggesting something that could be more generally accepted in a world where the translator has assumed a central role; that this trust in the translator as a competent spokesperson need not rely on the norm of transparency, since this very convention works against translating as a bona fide operation.

Are we not past the translator/traitor wordplay? Should we not assume that the pact of trust in translation as something original is contingent upon that other trust, which, according to Steiner, is the first condition of the translator's "hermeneutic motion" (Steiner 1975/1998: 310-320), the trust that the translator places in drawing sense from the author's work, the trust that guides the investment in becoming, I repeat, unisonous. We know absolute coincidence is a utopia: the translator is only a reader, albeit an extremely informed one, who has constructed an author for him or herself and a situated audience as well. In the case of Nabokov's Lolita, the multiple alignments and consequent divergent allegiances to be made with the implied author will arguably contribute to increasing the dissonance of translated discourse. But the in-betweenness, where the translated nature surfaces, is perhaps, after all, the most consonant means of transmitting the effect of heteroglossia, or "other-languagedness," as Bakhtin envisioned it: the variety of registers and languages by which a literary fiction invites us to engage with ideational and cultural differences (ParkFuller 1986).

\section{Conclusion}

Translation has not only become more visible due to its academic institutionalization and to a growing attention to its practice on the part of cultural agents, it has also become both a theme and device of our contemporary fiction. On the cusp of the $21^{\text {st }}$ century, novels such as Milorad Pavic's Dictionary of the Khazars (1988), Erik Orsenna's Deux Etés (1997), or Leila Aboulela's The Translator (1999) triggered the fictional thematization of an activity whose value has increased in advanced economies and which holds deep potential for conflict and resolution in the complex intercultural encounters of our globalized world. ${ }^{13}$ Currently, a greater bulk of fiction - postcolonial and diasporic narratives - thematize translational relations arising from the struggles of hybrid identities in dislocation or in cultural borders, with inter- or multilingual representations and (self-) translations.

The implications of translated literature $v i s-\grave{a}$-vis the source text regarding metalinguistic passages or the representation of linguistic hybridity have been underscored in the past by many self-conscious translators, through recourse to prefaces and footnotes. If the translator is a rising protagonist, one could expect that s/he might now take bolder steps in what regards his/her engagement in the discursive presence of a literary composition, assuming the singular co-authorship of one who writes what s/he has read, confident that the pact of trust with the reader implies an awareness of mediation. However, if the prospects for the industry of translation tend to shun personal creativity in favor of the mechanics of communication, ${ }^{14}$ and trade 
publishing follows a conservative stance that applies mechanisms of "containment" to the disruption of monolingual norms (Lennon 2010), the differential ethos of translated literature risks being tamed, if not totally subdued.

I have defended selective non-translation not only as an intervening strategy that involves overhearing the source-text's language, but also the translator's deliberative ethos. The case presented here is quite particular, but my overview of instances of application of such strategy indicates, in the comparison of my own translation of Lolita with previous ones, that a foreignizing tendency, namely the presence of the source-language, is not necessarily on the rise, since the first translation by Brenno Silveira resorted prodigally to loanwords, whereas subsequent ones favored domestication. My publisher tended to think of translation as an activity for a monolingual readership that would rather be deaf to nuances. Vladimir Nabokov's work, because he was himself translating or writing in-between tongues, destabilizes precisely the reading mind that takes language as a given means of expression, instead of performance, a spectacle to/of others. It demands the reader to be alert to assumptions about nativeness and authority of voice(s). I have suggested that such awareness can also be reinstated by finding a pragmatic way out of the conflict between editorial conventions and the literary translator attending to the defamiliarizing performativity of language(s). To think of translation as a genre that can be literary - with the narratological specificity of a "second-hand" author who is the reader of the text in its first language(s) - would help to promote both the translator's voice and the reality of multilingual literature. The last word has not yet been said about voice in translated literature, but I have tried here to put to the service of theory the discomfort I feel when asked to eliminate in a translation the conflict with the alienating language of writing, in a literary practice that I also see as a balance between mediation and alterity.

\section{ACKNOWLEDGMENTS}

I would like to thank Jeff Childs and Edgardo Medeiros da Silva for the linguistic revision, Emron Esplin and Astradur Eistensson for commenting on earlier versions of this work, and META's peer-reviewers for their helpfulness in restructuring its arguments.

\section{NOTES}

1. For translating Lolita, Nabokov's most famous novel first published in 1955 and expanded with an important afterword in 1956, I used the text and notes of:

NAвокоv, Vladimir (1955/1991): The Annotated Lolita. Introduction and notes by Alfred AppeL, Jr. New York: Random House.

The discussion in this study refers to the following translations:

NАвокоv, Vladimir (1955/1959): Lolita. (Translated by Brenno Silveira) Rio de Janeiro: Editora Civilização Brasileira.

Naвокov, Vladimir (1955/1968): Lolita. (Translated by Brenno Silveira) $2^{\text {nd }}$ ed. Rio de Janeiro: Biblioteca Universal Popular.

NAвокоv, Vladimir (1955/1974): Lolita. (Translated by Fernanda Pinto RodRIGUes) Lisboa: Dom Quixote.

NАвокоv, Vladimir (1955/1994): Lolita. (Translated by Jorio DAuster) São Paulo: Companhia das Letras.

NАвокоv, Vladimir (1955/2011): Lolita. (Translated by Sérgio Flaksman) Rio de Janeiro: Objetiva. Naвокоv, Vladimir (1955/2013): Lolita. (Translated by Margarida VALE DE Gato) Lisbon: Relógio d'Agua. 
2. The backdrop against which Nabokov stages his speech may be paralleled with the discourse of Lolita's declared precursor, Edgar Allan Poe, in "The Philosophy of Composition," with its exhibition of "the properties of the literary histrio." See PoE, Edgar Allan (1849/1984): Essays and Reviews. In: Gary Richard Thompson, ed. New York: The Library of America, 4.

3. Klinger uses the term "hybrid English" as synonymous with Ashcroft, Griffiths and Tiffin's (2002) proposal of (non-capitalized) "english," to differentiate postcolonial varieties from "metropolitan English" (Klinger 2015: 7). I believe the term can ultimately be extended to refer to all nonindigenous use of English, and thus may also be used to designate Nabokov's literary experiment with American English.

4. A few passages in Lolita seem to contradict Klinger's argument that "translational mimesis and represented self-translation are mutually exclusive" (Klinger 2015: 17) - a position I do not quite understand unless she means they cannot coexist in the same illocutionary act; even so, there is at least one instance in Lolita that questions Klinger's grounds for mutual exclusion, the argument that "translator and translatee cannot be the same textual agent" since they "inhabit different narrative levels" (Klinger 2015: 17). In the following passage, Humbert Humbert reports Lolita's speech through a euphemizing translation for his own benefit as well as for other possible narratees: "She used, in all insouciance really, a disgusting slang term which, in a literal French translation, would be souffler" (Nabokov 1955/1991: 277).

5. Lolita was thrice translated for the Brazilian trade book market, by Brenno Silveira in 1959 (though for this study I could only check the 1968 reprint), Jorio Dauster in 1994, and Rubem Siqueira and Sérgio Flaksman in 2011, but the translation I consulted more often, since it was immediately available for me in European Portuguese, was that of Fernanda Pinto in 1974 (see note 1 for references). Unlike what many fellow literary translators declare, I choose to look up whatever previous versions of a commissioned translation I can find, since I feel that my job is also to endow a text with its fair afterlife in my time and place. I am also fond of the "retranslation" hypothesis: "Later translations (same ST, same TL) tend to be closer to the original than earlier ones" (Alvstad and Rosa 2015: 14).

6. Poe, Edgar Allan (1849/1969): Annabel Lee. In: Thomas Ollive Mаввотт, ed. Collected Work of Edgar Allan Poe. Vol. I. Cambridge: Belknap Press of Harvard University, 478-479.

7. According to Edel-Roy's study of Nabokov's Russian Lolita, the transcription uoterpruf denotes Nabokov's fidelity to the English version (and language): "signale [. . . la possible polysémie du terme, qui peut signifier «imperméable» mais aussi «la preuve [ou l'épreuve?] de l'eau” (Edel-Roy 2010: 5). Nabokov's explanation for undertaking the Russian translation of the novel himself might imply a certain degree of perplexity with the first French translation's "Frenchification" of cultural references and toponyms (Couturier 2000: 522). For my part, I tried to legitimize my own translation options through an attempt to find out how Nabokov went about his Russian version, though my ignorance of the language prevented me from getting much further than what I have learned from Edel-Roy: it is still a novel whose referential background is American, and it contains a number of loanwords, transcriptions of English in the Russian alphabet, as the abovementioned uoterpruf, or gèrl-čajl'd' for girl-child.

8. More recently, however, Stratford (2008) expressed her bafflement with both standardizing translators and pessimist theoreticians on the possibility of translating linguistic hybridity.

9. I am alluding to A. M. Homes's controversial novel on the mania of female pederosis. See Homes, Amy M. (1996): The End of Alice. New York: Scribner.

10. This is another instance where, in the translation, the allusion to language as object of representation disconnects with the language being used as medium; as for the pun, it is somehow lost if the reader does not trace it back to the original English; two of the previous translations opted for explicitation, either in a footnote (Nabokov 1955/1974: 121) or in-text (in Nabokov 1955/1974: 171, Dauster adds "por soar como se fosse a lei Homem" / "because it sounds as if it were the law of Man").

11. Lolita is discussed at length in Booth's The Rhetoric of Fiction. Chapter 13 and its ethics are declared conflictual, a statement that is revised in the second edition's afterword (Booth 1983: 419).

12. Alvstad notes, furthermore, that the translator need not always work under erasure and that there might be a "slightly different" pact where "precisely because of [. . . instances when the voice of the translator surfaces," the readers believe that they can interpret the text accurately in spite of it being a translation. She does, however, maintain that readers are not likely to "attribute this translatorial presence to an implied translator" (Alvstad 2014: 281). This position follows Ferreira Duarte (2012), who maintains that paratextual material and translator's footnotes offering a rationale for 
the (un)translatable are rhetorical constructions "reembedding the institutional regime of translation" (Alvstad 2012: 31).

13. PAvic, Milorad (1984/1988): Dictionary of the Khazars: A Lexicon Novel in 100,000 words. (Translated by Christina Pribicevic-Zoric) New York: Alfred A. Knopf; Orsenna, Erik (1997): Deux Etés. Paris: Fayard; Aboulela, Leila (1999): The Translator. New York: Black Cat.

14. The discrepancy between the investment in service providing of the European Union's DirectorateGeneral for Translation and the decrease in exchange of translated literature is currently a concern of the European Society of Authors-ESA. See Grelier, Pauline (7 November 2013): EU: Translation in a Market Economy. CaféBabel. Consulted on 15 April 2016, <https://cafebabel.co.uk/culture/ article/eu-translation-in-a-market-economy.html>.

\section{REFERENCES}

Alvstad, Cecilia (2014): The translation pact. Language and Literature. 23(3):270-284.

Alvstad, Cecilia and Assis Rosa, Alexandra (2015): Voice in retranslation: An overview and some trends. Target. 27(1):3-24.

Amis, Martin (1992): Lolita reconsidered. The Atlantic Monthly. 270:109-120.

Ashcroft, Bill, Griffiths, Gareth, and Tiffin, Helen (2002): The Empire Writes Back: Theory and practice in post-colonial literatures. $2^{\text {nd }}$ ed. London/New York: Routledge.

Bakнtin, Mikhail Mikhailovich (1981): The Dialogic Imagination: Four Essays. (Translated by Michael Holquist and Caryl Emerson) Austin: University of Texas Press.

Barrento, João (2002): O Poço de Babel. Lisbon: Relógio d'Água.

Berman, Antoine (1985/2000): Translation and the Trials of the Foreign. (Translated by Lawrence Venuti) In: Lawrence Venuti, ed. The Translation Studies Reader. New York/London: Routledge, 284-297.

BoAse-Beier, Jean (2011): A Critical Introduction to Translation Studies. London: Continuum. Boотн, Wayne (1961/1983). The Rhetoric of Fiction. $2^{\text {nd }}$ ed. Chicago: University of Chicago Press. Boyden, Michael, and Goethals, Patrick (2011): Translating the Watcher's Voice: Junot Díaz's The Brief Wondrous Life of Oscar Wao into Spanish. Meta. 56(1):20-41.

Capranzano, Vincent (1995): The Postmodern Crisis: Discourse, Parody, Memory. In: Amy Mandelker, ed. Bakhtin in Contexts: Across the Disciplines. Evanston: Northwestern University Press, 137-150.

Chatman, Seymour (1978): Story and Discourse: Narrative Structure in Fiction and Film. Ithaca: Cornell University Press.

Couturier, Maurice (2000): Traduire Lolita. Revue des études slaves. 72(3-4):521-529.

EdEL-Roy, Agnés (2010): Lolita, ou «l'ombre d'une branche russe». Étude de l'auto-traduction. Miranda: Revue pluridisciplinaire du monde anglophone. 3:23 p. Consulted on 12 April 2016, $<$ http://miranda.revues.org/1536>.

Ferreira Duarte, João (2012): Trusting translation. Anglo Saxonica. 3(3):17-38.

FolKART, Barbara (1991): Le Conflit des Énonciations: Traduction et Discours Rapporté. Montréal: Les Éditions Balzac.

García Vizcaíno, María José (2008). Cisneros' Code-Mixed Narrative and Its Implications for Translation. Mutatis Mutandis. 1(2):212-224.

Granqvist, Raoul J. (2003): A Postcolonial Grammar of Translation. Chinua Achebe's Things Fall Apart as a Metonymic Text. In: Angelina E. Overvold, Richard K. Priebe, and Louis Tremaine, eds. The Creative Circle: Artist, Critic, Translator. Trenton/Asmara: Africa World Press, Inc., 59-71.

Grutman, Rainier (1997): Des langues qui résonnent. L’hétérolinguisme au XIXe siècle québécois. Montréal: Fides.

Hermans, Theo (1996): The Translator's Voice in Translated Narrative. Target. 8(1):23-48.

Hermans, Theo (2007): The Conference of the Tongues. Manchester: St. Jerome.

House, Juliane (2001): Translation Quality Assessment: Linguistic Description versus Social Evaluation. Meta. 46(2):243-257. 
Klinger, Susanne (2015): Translation and Linguistic Hybridity: Constructing World-View. New York: Routledge.

Lennon, Brian (2010): In Babel's Shadow: Multilingual Literatures, Monolingual States. Minneapolis: University of Minnesota Press.

May, Rachel (1994): The Translator in the Text: On Reading Russian Literature in English. Evanston: Northwestern University Press.

Meylaerts, Reine (2006): Heterolingualism in/and translation: How legitimate are the Other and his/her language? An introduction. Target. 18(1):1-15

Park-Fuller, Linda M. (1986): Voices: Bakhtin's Heteroglossia and Polyphony, and the Performance of Narrative Literature. Literature in Performance. (7):1-12.

Phelan, James (2007): Estranging Unreliability, Bonding Unreliability, and the Ethics of Lolita. Narrative. 15(2):222-238.

Schiavi, Giuliana (1996): There is Always a Teller in a Tale. Target. 8(1):1-21.

Sмiтh, Murray (1995): Engaging Characters: Fiction, Emotion, and the Cinema. Oxford: Clarendon Press.

Steiner, George (1975/1998): After Babel: Aspects of Language and Translation. $3^{\text {rd }}$ ed. Oxford: Oxford University Press.

Steiner, George (1998): Errata: An Examined Life. New Haven: Yale University Press.

Sternberg, Meir (1981): Polylingualism as Reality and Translation as Mimesis. Poetics Today. 2(4):221-223.

Suchet, Myriam (2013): Voice, Tone and Ethos: A Portrait of the Translator as a Spokesperson. In: Kristiina Taivalkoski-Shilov and Myriam Suchet, eds. La traduction des voix intratextuelles/Intertextual Voices in Translation. Montréal: Éditions québécoises de l'œuvre, 159-184.

Stratford, Madeleine (2008): Au tour de Babel! Les défis multiples du multilinguisme. Meta. 53(3):457-470.

Toury, Gideon (1991): What are Descriptive Studies into Translation Likely to Yield apart from Isolated Descriptions? In: Kitty M. van Leuven-Zwart and Ton NaAijkens, eds. Translation Studies: The State of the Art. Amsterdam/Atlanta: Rodopi, 179-192.

Vale de Gato, Margarida (2015): Will the Aliens Come Home? Diaspora and Translation in Portuguese-American Literature. In: Rita Bueno Maia, Marta Pacheco Pinto and Sara Ramos Pinto, eds. How Peripheral is the Periphery: Translating Portugal Back and Forth. Essays in Honor of João Ferreira Duarte. Newcastle upon Tyne: Cambridge Scholars Publishing, 275-295.

Venuti, Lawrence (1995): The Translator's Invisibility. London/New York: Routledge.

Venuti, Lawrence (1995/2008): The Translator's Invisibility. $2^{\text {nd }}$ ed. London/New York: Routledge Zauberga, Ieva (2001): Discourse Interference in Translation. Across Languages and Cultures. 2(2):265-276. 